\title{
On the Use of Option Pricing Models to Analyze Deposit
}

\section{Insurance}

$\mathrm{T}$ FAILURE rate of banks and thrifts has exploded over the past decade, making reform of the deposit insurance system a topic of considerable interest to regulators, bankers, and economists. As illustrated by figure 1, which shows the total number of failed commercial banks lexcluding thrifts) for each year since the chartering of the Federal Deposit Insurance Corporation (FDIC), the annual number of commer. cial bank failures in each of the last several years has exceeded its previous peak, attained during the Great Depression. The status of the thrift industry is even more grim, with losses to the Federal Savings and Loan Insurance Corporation (FSLIC) estimated at $\$ 160$ billion or more. The primary consequence of these failures for public policy is the enormous losses, especially to the FSLIC, as depositors in these failed institutions are reimbursed.

This article considers a particular set of economic tools used to evaluate deposit insurance. ${ }^{*}$ Option pricing models are among the techniques available for analyzing the deposit insurance system. These models can be used to assign specific values to the claims of each of the interested parties involved in the deposit insurance system - the insurer, financial institutions, and depositors. Such valuations can then be used, for example, to estimate the net value of the government's insurance fund or to determine a fair price that a bank should pay for its insurance. More generally, by comparing insurance valuations with different model parameters, one can investigate the system of incen. tives under a given regulatory scheme, such as the risk incentives for bank shareholders and depositors under the present system. Finally, comparisons of insurance values and incentives can be made across various proposed regulatory schemes. These applications are illustrated be. low with some examples.

The usefulness of option pricing models for evaluating deposit insurance is of special interest for two reasons. First, the consensus among the interested parties is that the present deposit insurance system has contributed to the current crisis. Second, in the context of this debate, a number of economists have used the
This article does not address the issue of why we should have deposit insurance. The rationale for the current system of bank fegulation and for deposit insurance in particular is based on two related principles: protection of the depositor and the mitigation of contagious bank wuns. See FDIC (1984) and U. S. Treasury (1985). Benston and
Kaufman (1988) identify three reasons for bank regulation in addition to the two traditional rationales, namely distuption to communities from localized bank failures, moral hazard induced by deposit insurance and restrictions on competition. 


\section{Figure 1 \\ Bank Failures (Insured and Uninsured)}

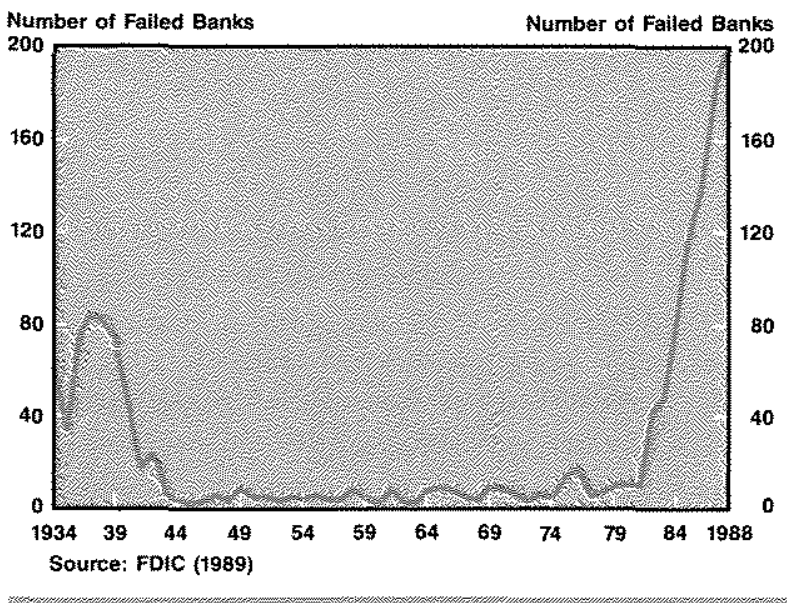

modern theory of option pricing to explain the incentives and measure the costs both of the current system of deposit insurance and of some suggested alternatives. This paper presents the basic theory of option pricing, explains how it can be applied to deposit insurance, and analyzes some of the issues involved in its use.

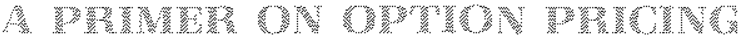

This paper presumes no knowledge of options or of the various economic models that have been used in the academic literature to assign values to options. Thus, it begins with a brief description of options and some of the major contributions to the theory of pricing options that have been made in the past two decades.

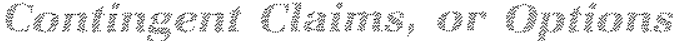

A call option is a legal contract that gives its owner the right to buy a specified asset at a fixed price on a specified date. ${ }^{2}$ Similarly, a put option gives its owner the right to sell a specified asset at a fixed price on a specified date. Option contracts are usually sold by one party to another ${ }^{3}$ The person who owns an option contract is called the holder of the option. The per- son who sells an option contract - that is, the person who will be compelled to perform if the option holder invokes her right as specified in the contract - is called the writer of the option. The act of invoking the contract is called exer. cising the option. The fixed price identified by the option contract is called the striking price. The date at which the option can be exercised is called the expiration date of the option.

These legal contracts are probably best known by the stock options that are bought and sold by brokers in the trading pits of organized options exchanges in Chicago, New York and elsewhere. In addition to options on common stock, there are active markets for options on agricultural commodity futures, foreign currencies, stock index portfolios, and government securities, to name only a few. The definition of an option, however, does not limit the term to those contracts actively traded on the floors of organized financial exchanges. By definition, an option is any appropriately constructed legal contract between the writer and the holder, regardless of whether it is ever traded.

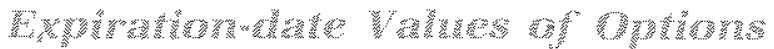

Consider now the value to the holder of an expiring put option, as illustrated in figure 2 . The value of the underlying asset specified by the contract is given on the horizontal axis, while the value of the option itself is given on the vertical axis. The point $K$ on the horizontal axis is the specified striking price for the asset. If the value of the underlying asset is above the striking price on the expiration date, then the put option will not be exercised; anyone who truly wanted to sell the asset would do so outright at the going price, rather than using the option and receiving the striking price. In this case, the option expires worthless, and the option holder experiences no gain or loss on the expiration date.

On the other hand, if the value of the asset is below the striking price, then the holder will exercise her option and receive the striking
2This definition is a paraphrase of the definition given by Cox and Rubinstein (1985), p. 1. It describes a "European" option, which is distinguished from an "American" option. An American option gives its owner the right to buy at any time on or before the specified date.

They are sold, because options have a non negative value; because they are a right to buy (or sell) the asset, they do not compel the owner of the contract to do anything. Although they are valuable, nothing in the definition of an option requires that they be offered for sale; that is, their value does not depend on how they were obtained. 


\section{Figure 2 \\ Value of Put Option to Holder}

Expiration Value of Option

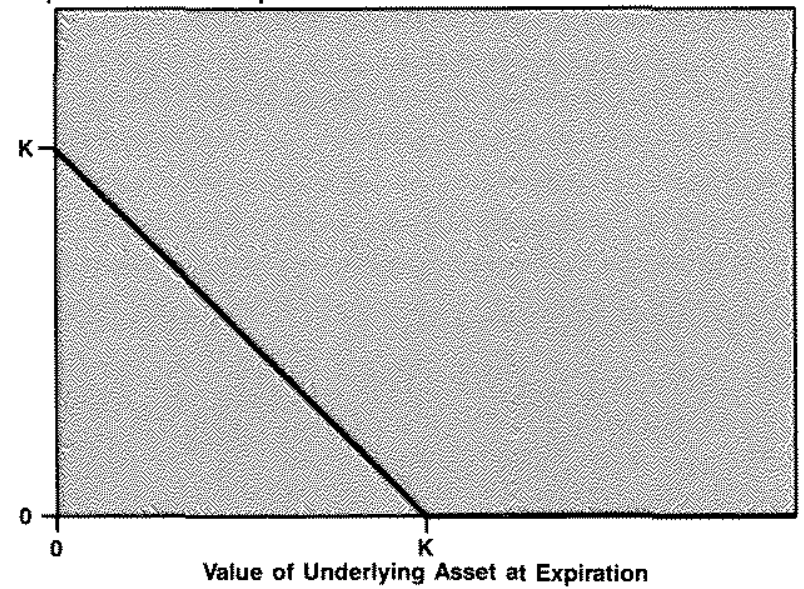

Figure 3

\section{Value of Put Option to Writer}

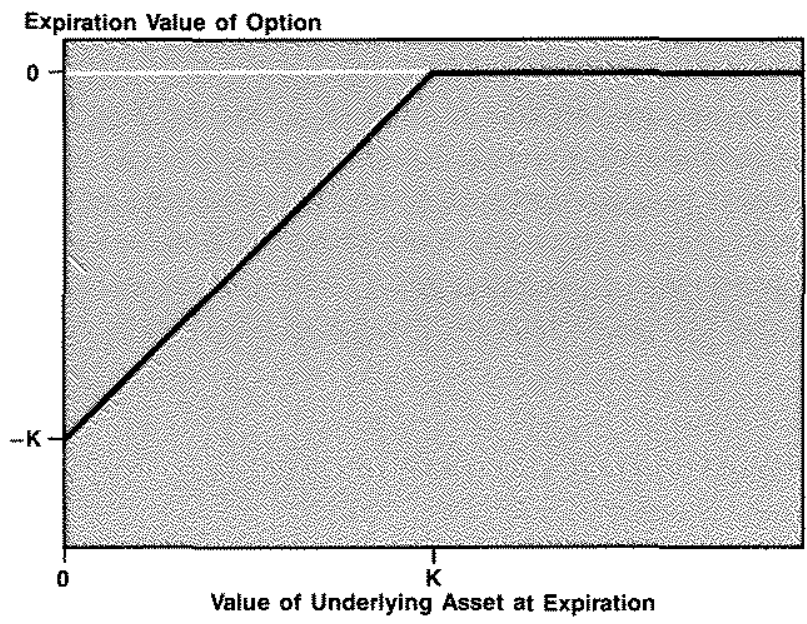

price for the asset. In this case, her net gain on the expiration date will be $\left(K-A_{T}\right)$, the difference between the striking price and the current price, since she can turn around and replace the asset immediately, if she wants to. Thus, the expiration value of the option and the decision about whether to exercise are contingent upon the value of the underlying asset at that time:

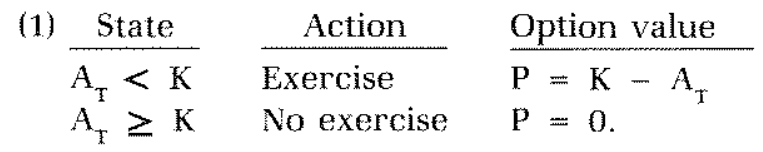

For this reason, options are also referred to as "contingent claims" on the underlying assets.

The corresponding net payoffs to the writer of the put option are given in figure 3 . Notice that his payoffs are exactly the inverse of those for the option holder. Also note that the payoff at expiration to the writer of an option is never positive; at best it is zero. It is for this reason that options are sold to the holder, rather than being given away free of charge. The price in. itially paid for the option - the option price or option premium - could be incorporated into the figures by simply shifting the holder's payoffs down and the writer's payoffs up by the appropriate amount.

The payoffs at expiration to the holder and writer of a call option are given in figures 4 and 5 , respectively. "The corresponding analysis for call options is precisely analogous to the analysis just given for put options.

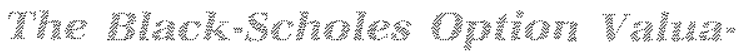

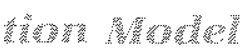

Having described the value of an option at expiration leaves the question of its value prior to expiration unanswered. Instead of being a simple function of $A$ and $K$, the value of an option before maturity depends on several additional factors. Although a number of bounds had been placed on the value of an unexpired option by using relatively simple arbitrage arguments, an important advance in the valuation of unexpired options was made by black and Scholes (1973).* They obtained an exact equation for the value of a put option under an unrestrictive set of assumptions. ${ }^{*}$ Their result has since been elaborated and generalized by others.

In their model, the value of an unexpired option depends on five things:
${ }^{4}$ For an exposition of the arbitrage bounds on option prices, see Merton (1973), or Cox and Rubinstein, ch. 4.

${ }^{5}$ Almost all derivations of option pricing models, including that of Black and Scholes, are stated in terms of call rather than put options. As it happens, this distinction is largely irrelevant, because call option valuations are readiy converted to put option valuations, and vice-versa, via an arbitrage relationship known as "put"call parity". Put- cail parity is an exact relationship for European options and an approximale one for American options (see Cox and Rubinstein, pp. 150-52); throughout this paper it is treated as exact. Put-call party is first presented by Stoll (1969).

Gne such generalization is found in the shaded insert. For a partial survey of option pricing models, see Cox and Rubinstein, ch. 7 . 
$\mathrm{K}=$ the striking price

$A=$ the current asset price

$\mathrm{T}=$ the time remaining to expiration

$a=$ the volatility of the asset price

$R=$ the risk-free interest rate.

Almost as notable is what the option's value does not depend on: any characteristic of the holder or the writer. ${ }^{7}$ Under their assumptions, Black and Scholes are able to include an option in a riskless portfolio. Such a portfolio must earn the risk-free interest rate, and they are able to use this result, along with an assumption about the probability distribution of the asset price, to identify an exact value, $P$, for a put option:

$P=\left(K \cdot e^{-R T}\right) \cdot N(X+\sigma \sqrt{T)}-A \cdot N(X)$,

where:

$$
\begin{aligned}
X \equiv & \frac{1}{\sigma \sqrt{T}}\left[\ln \left(K^{\bullet} e^{-R T}\right)-\ln (A)\right]-1 / 2 \sigma \sqrt{T} \\
N(\bullet) \equiv & \text { the } \sqrt{\text { standard normal cumulative }} \\
& \text { probability function } \\
\ln (\bullet) \equiv \text { the natural logarithm function } & \\
e \equiv & \text { the base of the natural logarithm }
\end{aligned}
$$

Although this formula may at first appear complicated, a rough intuition can be provided relatively painlessly. First, $\mathrm{e}^{-\mathrm{RT}}$ is just the present value discount factor for $T$ periods at interest rate $\mathbf{R}$ with continuous compounding, so that $K \cdot \mathrm{e}^{-\mathrm{KT}}$ is the present value of the striking price. Keeping in mind that $\mathrm{N}(\mathrm{X}+\sigma \sqrt{\mathrm{T}})$ is a probability, the first term is the expected present value of the striking price at expiration, given that $A_{T}<K$. Similarly, the second term, $A \cdot N(X)$, is the expected present value of the expirationday asset price, again given that $A_{T}<K .{ }^{9}$ Thus, the value of the option is the expected present value of its value at expiration, given by condition 1 above.

Unfortunately, no easy, correct interpretation can be attached to the specific probabilities, $\mathrm{N}(\mathrm{X}+\sigma \sqrt{\mathrm{T})}$ and $\mathrm{N}(\mathrm{X})$, in the two terms. These

\section{Figure 4 Value of Call Option to Holder}

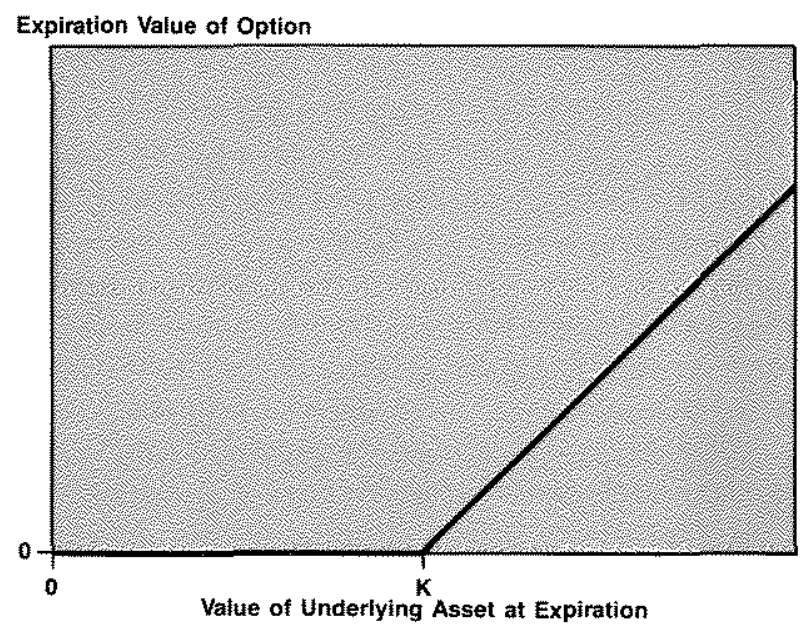

Figure 5 Value of Call Option to Writer

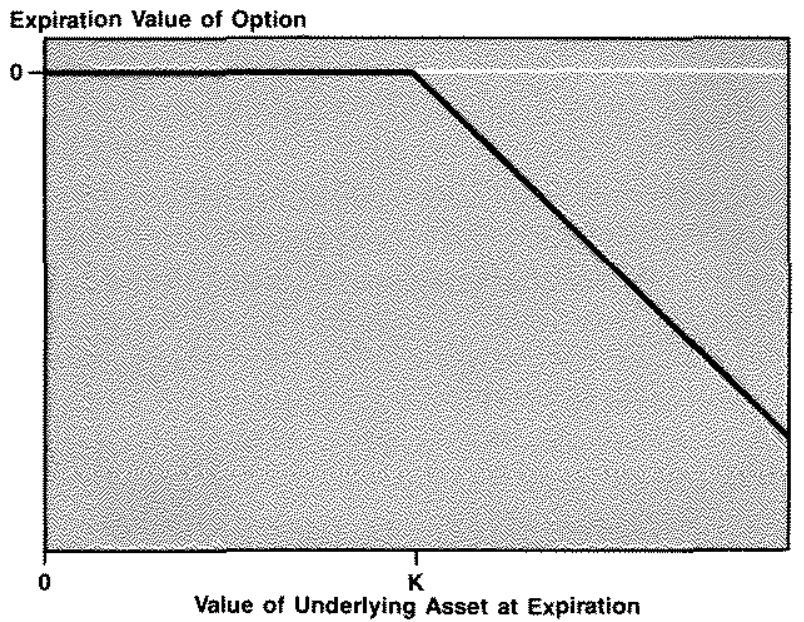
probabilities are closely related to the probability that $A_{T}<K$, but they are not quite the same, because the present value of the striking price is known with certainty, whereas the pre. sent value of the asset's price on the expiration day, $A_{T} \cdot e^{-R T}$, is not; the current asset price, $A$, appears instead.

Malliaris (1983) for a mathematically advanced approach or to Cox and Rubinstein, ch. 5 , for a longer but less sechnical derivation.

The corresponding expected present values for the case when $A_{r m}$ is greater than $k$ are both zero, because then the expiring option is worthless and will not be exercised; hence, this possibility adds nothing to the current value of the option.
7For example, one might suspect that the holder's attitudes toward risk or her beliefs about the asset price at expira. tion should influence the option's value to her. This is not the case, however. Also note that four of the five factors, at least theoretically, are well-defined and directly obser vable al the time of valuation. The exception is asset volatility, which must be estimated from observable factors; see Cox and Rubinstein, pp. 280-87, for an example of an estimation technique.

${ }^{8}$ A full derivation of the formula is fairly involved and will not be presented here. Interested readers are referred to 
In spite of its complexity, the option pricing equation is still a useful tool. In one sense, the formula can be treated as a black box in which the five parameters $(K, A, T, o$ and $R$ ) enter at one end, and the value of the put option, $P$, comes out at the other; a computer spreadsheet or calculator can be programmed to perform the intervening calculations defined by the formula. For example, if the current asset value is $A=\$ 985$, the standard deviation of asset returns is $\sigma=0.3$ percent, the striking price of the option is $K=\$ 1000$, the time to expiration is one year, and the riskless interest rate is 8 percent per year, then the Black-Scholes equation tells us that the put option is worth $\$ 85.45$. Figure 6 graphs the Black-Scholes value of a put option for a range of current asset values from zero to $\$ 1500$, where the values of the other four parameters are the ones just given.

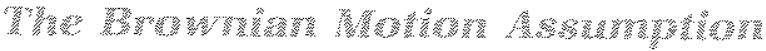

Not surprisingly, the distribution of asset prices is a crucial factor in determining the exact form of the option pricing equation. In their derivation, Black and Scholes assumed that the price of the underlying asset progressed randomly through time according to geometric Brownian motion. This is the assumption that leads to the specific normal probability functions in their pricing equation.

Brownian motion was first used to describe the random progress of a single molecule through a gas from a given starting point. ${ }^{\text {to }}$ It is a mathematical model of motion that identifies the way the particle can move. Three restrictions are implied by Brownian motion:

1) The path followed must be continuous; ${ }^{11}$

2)All future movements are independent of all past movements; ${ }^{12}$

3)The change in position between time $s$ and time $t$ is normally distributed with mean equal to zero and a standard deviation equal to $o \sqrt{(t-s)}$.

Note that standard deviation is directly proportional to the amount of time that has passed.

10We are here concerned with only a single dimension of motion, for example, the East.West coordinate of the molecule or the price of an asset.

"Although this may be true of molecules, it need not be the case for asset prices, as is considered in the shaded in. sert on Merton's jump-diffusion model.

${ }_{12}^{12}$ This implies, for example, that the molecule cannot build up momentum or that prices do not have a predictable

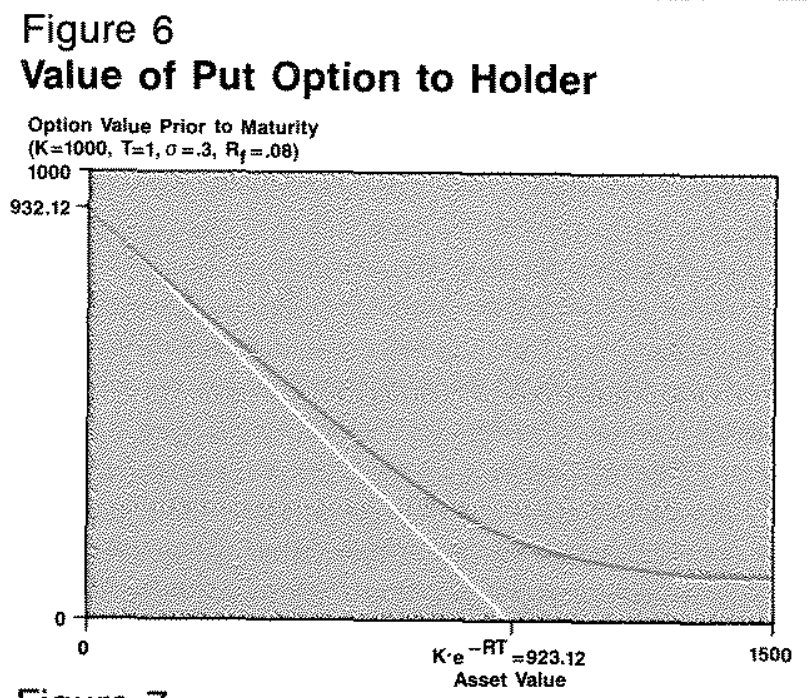

Figure 7

Value of Net Asset Position

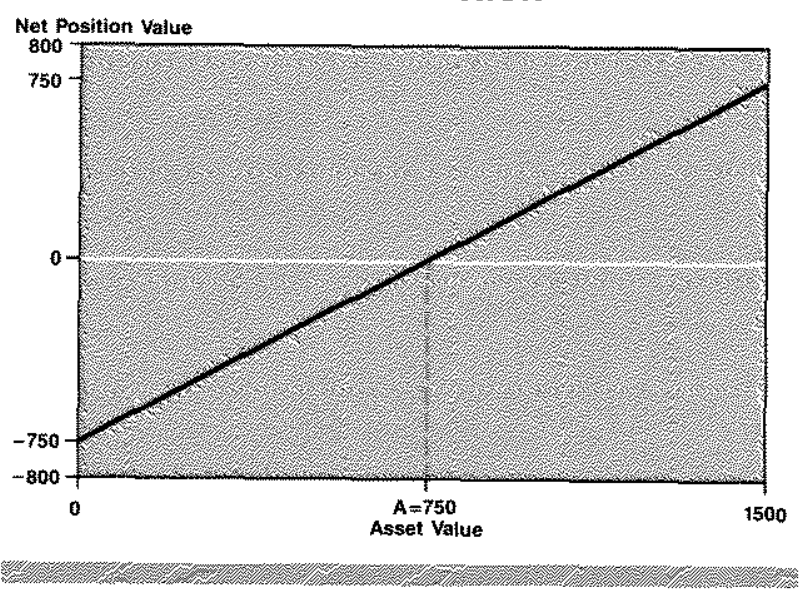

Thus, the longer one waits, the less certain one is about the location of the molecule, or, in our case, the price of the asset.

Simple Brownian motion is not completely satisfactory for describing asset prices, however. While a normally distributed random variable can take on negative values, an asset price cannot. Therefore, geometric Brownian motion, a variant, is assumed for the Black-Scholes model. ${ }^{13}$ Under geometric Brownian motion, the third restriction is modified, so that the logarithm of the change in position, rather than the

trend. It does not mean that the future location is independent of the past location.

${ }^{13}$ By way of terminology, simple Brownian motion (also known as arithmetic Brownian motion) and geometric Brownian motion are examples of the Wiener process (also known as the Gauss-Wiener process), which, in turn, is a special case of the lito process. 
change in position itself, is normally distributed with mean zero and standard deviation $\sigma \sqrt{(\mathrm{t}-\mathrm{s})}$. This distributional assumption gives us the specific functional form which appears in the BlackScholes equation. Thus, this assumption is important: a different distribution would generally yield a different pricing equation, as illustrated by Merton's (1976) jump-diffusion option pricing model, which is presented in the shaded insert on the opposite page.

\section{W}

The option pricing equation has the paradoxical property that, although risk (as measured by volatility in the asset price) is itself a factor in the option's value, the attitudes toward risk of the holder and the writer (and anyone else) are not. The option's value is a function of five variables, none of which depends on the characteristics of the individuals involved. Black and Scholes achieved this by showing that the option can be made part of a completely hedged (that is, riskless) portfolio. Any option writer who offered a risk discount when selling an option would find himself selling many option contracts to investors who, in turn, could hedge the risk completely and pocket the risk discount as an arbitrage profit. It is for this reason that the discount rate which appears in the pricing equation is the risk-free rate of interest, and attitudes toward risk are irrelevant to the value of the option.

To see how the hedged portfolio works, consider the value of a put option to the holder before expiration, depicted in figure 6 , and the value of the underlying asset purchased for the amount $A$, depicted in figure 7 . The value of the net asset investment increases one for one as the price of the asset increases, and the value of the option decreases, although not in a constant proportion.

The key to the hedged portfolio is to buy put options and underlying assets in the appropriate ratio, so that, when the asset price increases, the increase in value of the net asset investment will be precisely offset by the decrease in value of the option position, and vice-versa. This implies a riskless total portfolio. Of course, the appropriate ratio (called the "hedge ratio" or "option delta") also changes as the asset price changes, because the value of a put option does not decrease as a constant proportion of the asset value (the put option's value is represented by a curved linel. This implies that the holder of a completely hedged portfolio must continuously adjust the relative proportions of options to assets if the hedged portfolio is to remain riskless. Black and Scholes presume that at least some investors are large and sophisticated enough to do this.

Because the risk of an option can be completely diversified, the risk-free rate is the appropriate interest rate to use for discounting the option's uncertain payoff at expiration. Nevertheless, the risk (defined as price volatility) of the underlying asset is a factor in the option's value, because asset risk affects the expected value of the option's payoff. This is due to the limited liability nature of the option. Although increasing the volatility of the asset price increases both the chance of getting a very high expiration-day asset price and the chance of getting a very low expiration-day asset price, the bad (high price) outcomes all have a weight of zero in the put option valua. tion, while the good (low price) outcomes have a weight of $\left(\mathrm{K}-\mathrm{A}_{\mathrm{T}}\right)$. The volatility of the option's value also increases with that of the asset price, but the volatility of the option's value is irrelevant, because it can be completely hedged.

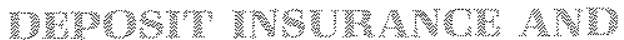 (n)}

The analysis of deposit insurance is a natural, albeit not obvious, extension of option pricing models. The connection between the two comes through the limited liability property common to both options and common stock. ${ }^{4}$ This property implies an "expiration-day" payoff for deposit insurance that can be modeled as an ordinary put option. Similarly, other claims on a financial intermediary's assets can be modeled as options or combinations of options. The benefit is that, given such a model, option pricing theory allows us to assign values to each of the claims. These values are the key to option pricing's usefulness in this context, because they allow two sorts of comparisons to be made.

First, variations in the parameters of the option pricing equation can be considered. ${ }^{15}$ Such variations are of special interest, because, in the
14This connection was first made by Black and Scholes and firsi applied to deposit insurance by Merton (1977).
15For example, in Black and Scholes' model, the five parameters: $K, A, T, \sigma$ and $R$ would be varied. 


\section{Merton's Jump-Diffusion Model}

The Black and Scholes (1973) derivation of an option's value was based in part on a particular assumption about the random behavior of the price of the underlying asset. Their assumption of geometric Brownian notion as a description of the mevements of asset prices is by no means the only possibili ty. In general, different assumptions about the statistical properties of asset price behavior produce different valuation equations for an option on that asset. Merton's jumpdiffusion model is one of several alternative formulations that have been developed?

Just as arithmetic Brownian motion was not an apt model of asset price movements, em. pirical research suggests that geometric Brownian motion, at least for some assets, is similarly inappropriate. An alternative, pro posed by Merton (1976), is a combination of geometric Brownian motion with random, discontinuous iumps in the asset price, such as night occur at the announcenent of some news event? This armangement viblates the first condition for Brownian motion and modifies the third condition again 3 When a jump occurs, the asset price is abruptly shifted by a random amount, the logarithr of this shif is nommally distributed, analogously to geometric Brownian notion.

This new process has two important inplications for the option pricing nodel. First. the option pricing equation is different from the Black and Seholes formula, since it nust accomt for the new jumps. If we relabel the Black-scholes value as $\mathrm{P}_{\mathrm{bs}}=\mathrm{P}_{\mathrm{b}}(\mathrm{K}, A, \mathrm{~T}, \mathrm{o}, \mathrm{R})$, then we can write the Merton formula as a function of the Black-Scholes value:

$$
\begin{aligned}
& P_{n}=\sum_{i=0}^{\infty}\left[\beta_{i} \cdot P_{b},\left(K, A, T, \theta_{i}, P\right)\right. \\
& \left.+(1-\beta):\left(K \cdot e^{-R T}-A\right)\right]
\end{aligned}
$$

where:

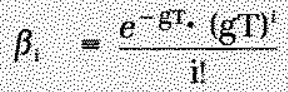

$$
\begin{aligned}
& \theta_{1}=\sqrt{\left(\sigma^{2}+\mathrm{h}^{2} 10\right.} \\
& g \text { : the Poisson frequency of jumps } \\
& h^{2}=\text { the variance of the shift distribution }
\end{aligned}
$$

Not surprisingly, the Merton equation is more complicated than the Black and Seholes equation. Nevertheless, it is still a function of variables that are at least hypothetically observable: ${ }^{4}$

Second, the presence of the jumps complicates the diversification problem. The sim. ple hedging portfolio used for the nlackScholes nodel will not do because even conlinuous rebalancing camnot insure the portfolios value at the jump points. If however. the imps are idiosyncratic that is, firm specifiel then their risk can still be elimi. nated by holding a well-diversified portfolio that ineludes the assets of many firms in many industries, If the jump disturbances are idiosyncratic, then the risk-free interest rate is still the appropriate discount rate for the expeeted option payoff and individual at. tiludes toward risk are not a factor in the options value before expination.

3The discontinuous umps arrive accolding 10 a Poisson process, which contorns to the second condition

Ih practice, the statistical parameters. 0 , hand 9 would have to be estimated, either from previous observations or via some other technique, The equation given here is a special case of a more general formulation given by Merton (1976). His derivation is of a call option price, which has been rearranged here ushg putcall parity.

detriment of the other. The risk-incentive problem presented below exemplifies this sort of application. Comparisons based on option pricing models indicate not only the direction, but also the magnitude, of such incentives. context of deposit insurance, some of the parameters can be controlled or influenced by the parties to the option contract. Thus, each party has a clear interest in influencing the parameters to his own benefit and therefore to the 
Second, various deposit insurance structures can be compared. The structure of deposit in. surance is defined here by the number and type of options pertaining to each of the in terested parties. Changes in deposit insurance structure are different from the parameter changes within an insurance structure, considered in the preceding paragraph. Thus, for example, the FDIC could use option models to estimate the net increase or decrease in the present value of the insurance fund caused by a switch from one structure to another; or it could examine the change in risk incentives occasioned by the same switch. Three different structures, illustrating some of the issues involved, are presented in the following examples. ${ }^{16}$

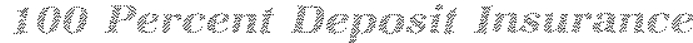 अ.}

To see how deposit insurance and options are related, consider the following simplified bank. ing scenario. A single banker both owns and runs a bank, a single large depositor provides the entire liability portfolio of the bank, and a single insurer, the $F D I C$, insures deposits and will liquidate the bark in the event of insolven cy. ${ }^{27}$ The liability portfolio consists of a single deposit due at year-end. Also at year-end, the FDIC examines the bank to determine the value of assets, which will, in turn, determine whether liquidation occurs. If the bank is economically insolvent, it is closed by the FDIC, which liquidates the assets at market values and pays off the depositor in full. ${ }^{18}$ If the bank is eco" nomically solvent, control remains with the banker, who can either renegotiate the deposit or liquidate the bank.

16Full coverage is considered first, because it is the simplest insurance structure possible, and because it approximates the current system of extensive coverage combined with the FDIC's tendency to arrange purchase and assumption transactions, rather than deposit payouts, for failed banks.

1The assumptions of a single owner-manager for the bank and a lone depositor are clearly broad abstractions from reality. The owner-manager assumption allows us to ignore principal-agent incentives; see Barnea, Haugen and Senbel (1985). Similarly, the assumption of a single depositor effectively precludes the ability of depositors to withdraw their funds individually without forcing an im* mediate closure of the bank. Although these are both important issues, the purpose of the present analysis is to if lustrate the general principles involved in the application of option models to deposit insurance, rather than to model a bank in its full complexity.

18The bank is defined as economically insolvent when the market value of its assets is less than the present value of its liability to the depositor. This terminology is meant to
Now consider the payoffs to the three in terested parties - banker, FDIC and depositor - when the year-end audit is performed. These payoffs are illustrated in figures $8-10$. Each party's year-end payoff is plotted as a function of the year-end value of the bank's assets. Note that the sum of the payoffs to all of the parties (obtained by adding the graphs vertically) equals the value of the bank's assets. These functions show how the bank's assets will be distributed after the audit is performed. Also note the shape of the payoff functions for the banker and the FDIC in effect, the banker's portfolio consists of the bank's assets, whose value is uncertain before the audit but known afterward, the bank's deposits, whose value is known to be $L$, and a put option with striking price $L$ written by the FDIC. ${ }^{13}$ The FDIC, on the other hand, has effectively written the put option on the assets of the bank and sold that option to the banker for the price of the deposit insur. ance premium. ${ }^{20}$ The depositor has issued the bank a risk-free loan, which pays off the amount $\mathrm{L}$, including accrued interest.

With this in mind, the usefulness of an option pricing model to evaluate deposit insulance becomes more apparent. An option pricing model provides an estimate of the actuarial dollar value of deposit insurance, as well as a tool with which to analyze the economic incentives that deposit insurance creates. The depositor, for example, has a portfolio, D, that is worth, at the beginning of the year, simply the present value of the deposit liability discounted at the riskless rate, $L \cdot e^{-R T}$; if his year-end payoff, $L$, is $\$ 1000$, and the riskless rate, $R$, is 8 percent, then the value of this portfolio at the beginning

contrast with an illiquidity, or legal insolvency, which is brought on by an inability to meet maturing short-term liabilities with liquid assets. The legal profession has a separate terminology for these two concepts; the "balance sheet test" is used to determine economic insolvency, and the "equity test" is used to determine legal insolvency. See Symons and White (1984), pp. 603-16, for an exposition. Since there are no short-term liabilities in the simplified world here, legal insolvency is not germane.

19The bank's deposits represent a "short" position, or bor rowing, for the banker. The net payoff shown in figure 8 can be gotten by drawing the individual payoff graphs for the components of the portfolio and adding these together vertically as before. This portfolio is also equivalent, via put-call parity, to a simple call option on the assets of the bank.

${ }^{20} \mathrm{Compare}$ figure 9 with figure 3 . The insurance premium is considered a sunk cost at the time of the audit and hence is not included in the graphs. 
Figures 8-10
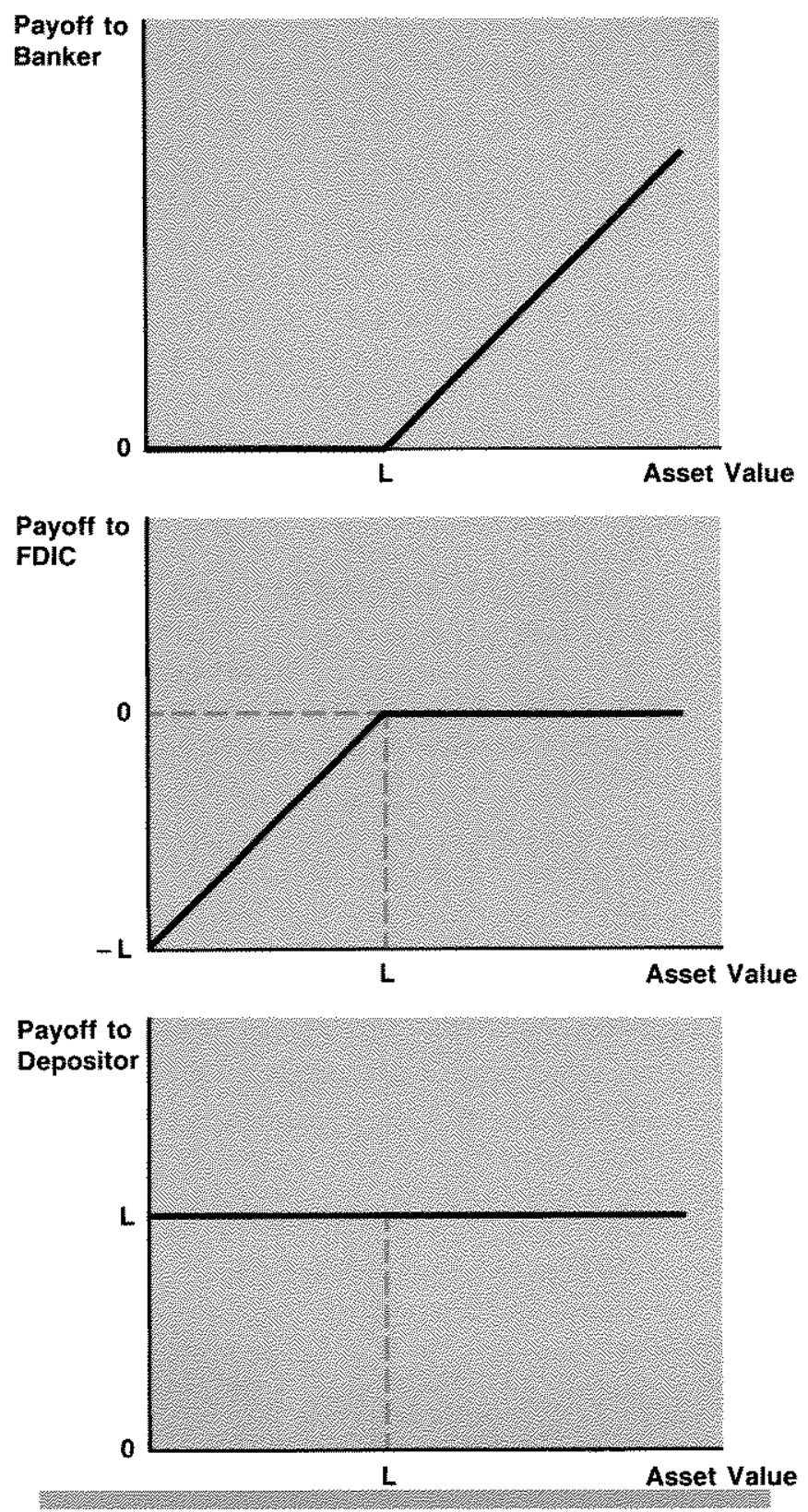

of the year is $\$ 1000 e^{-.08}=\$ 923.12$. The FDIC, on the other hand, has written a put option with striking price $L=\$ 1000$; if for example, the standard deviation of the bank's asset re. turns is $\sigma=0.3$ percent, and the current value of the banks assets is $\$ 985$, then the value of the FDIC's portfolio is given by the BlackScholes equation as $-\mathrm{P}=-\$ 85.45$.

Of particular interest are the incentives created by deposit insurance. Under 100 percent insurance, the depositor does not care about the value of the bank's assets, since he receives his deposit back with interest, regardless of the bank's condition. The banker, however, receives the positive equity capital, if the bank is solvent; if the bank is insolvent, the loss is charged to the FDIC. This "heads I win, tails you lose" arrangement is certainly not peculiar to banks; it applies to any corporate entity with limited stockholder liability. In the absence of other incentives, the banker will make the corporation as risky as possible. ${ }^{21}$

What is peculiar to banks under 100 percent flat-rate deposit insurance is the absence of such other incentives for the depositor and the banker to limit risk. Normally, creditors impose a risk premium on corporations, based on the riskiness of the firm's assets. ${ }^{22}$ By definition, flat-rate insumance implies that the FDIC charges no risk premium. Similarly, the depositors charge no risk premium, because they are fully insured. The result, in our simplified model, is that the banker has an ummitigated incentive to increase the riskiness of the bank's assets, while the FDIC has the inverse incentive to reduce the bank's risk-taking. ${ }^{23}$ The risk incentive implied by extensive, flat-rate deposit insurance is the impetus for most of the current proposals for deposit insurance reform. ${ }^{24}$ In analyzing both the cument system and proposed reforms, many authors have used option pricing models. ${ }^{25}$ 2ifecall that the value of an option to the holder increases with the volatility of the underlying asset. For the Black and Scholes model, risk is defined as the standard deviation of the logarithm of the asset's value.

22This is the function of bond rating services, such as Moody's and Standard and Poor's. See Barnea, Haugen, and Senbet, especially pp. 33-35, for an exposition of the risk-incentive problem.

23For this reason, risk-taking is restricted by extensive regulation of commercial bank activities. In practice, the banker's incentive may also be mitigated by the potential loss of a valuable bank charter or by nonpecuniary factors. for example, the potential loss of a bank manager's professional reputation in the event of a failure. These factors are beyond the scope of the option model.
${ }^{24}$ Reform proposals include: risk-based insurance premia risk-based capital requirements, larger capital requirements, reduced insurance coverage, depositor coinsurance, subordinated debt requirements, increased supervision and more stringent asset regulation. See White (1989) for a survey of current proposals.

${ }^{25}$ See, for example, Merton (1977, 1978), McCulloch (1981, 1985), Sinkey and Miles (1982), Pyle (1983, 1984, 1986), Brumbaugh and Hemel (1984), Marcus (1984), Marcus and Shaked (1984), Ronn and Verma (1986, 1987), Thomson (1987), Furlong and Keeley (1987), Pennacchi (1987a, $1987 \mathrm{~b}$ ), Osterberg and Thomson (1988), Flannery (1989a, 1989b), and Allen and Saunders (1990). 


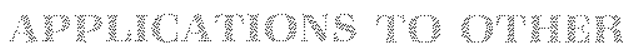

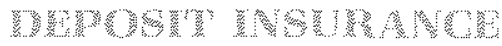

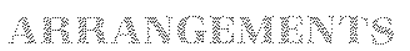

We can now extend the options model to other arrangements for deposit insurance, to evaluate their relative impacts. Two illustrative cases will be presented: a coverage celing clause and a deductible clause. A significant character. istic of both these cases is that they impose a portion of the bank's asset risk on the depositor. The FDIC benefits directly from such provisions, because they shift some potential losses directly to the depositors. In addition, impos:tion of a possible loss on the depositor mitigates the risk-incentive problem that exists under 100 percent, flat-rate deposit insurance. In general, the depositor will monitor the bank more closely and will require a higher interest rate to compensate for the possibility of default.

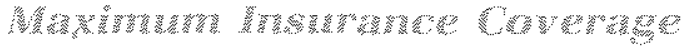

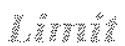

Although 100 percent coverage is ofter treated as the status quo de facto of federal deposit insurance, coverage extends legally only to the first $\$ 100,000$ per depositor per institution. ${ }^{26} \mathrm{~A}$ maximum coverage limit is a form of co-insurance, a technique used by insurers to reduce the moral hazard problem the tendency of insurance to alter the betavion of the insuredl. Other basic forms of co-insurance are the deductible and fixed proportional sharing of losses. ${ }^{27}$

The applicability of the maximum coverage limit considered here is complicated by the FDIC's current closure protocol. Bank closures by the FDIC can take one of two forms: purchase and assumption or deposit payout. Lnder a purchase and assumption closure, healthy assets and all deposits are transferred to another healthy bank, with the FDIC absorbing the problem assets and any net loss. ${ }^{28}$ This sort of transaction is best modelled by the 100 percent coverage considered above.
Under a deposit payout closure, the FDIC itself takes all of the bank's assets and liabilities into receivership. It then sells the assets and pays the depositors up to the maximum cover. age limit plus any excess of asset sales over insurance claims, distributed on a pro rata basis. As a result, this method is best modelled by the deductible considered below. The upshot is that the payoffs under the FDIC's maximum coverage limit do not conform to the familiar from, say, automobile or heath insurance) maximum coverage arrangement illustrated here.

Consider a maximum coverage limit of $\mathrm{M}$ dollars for the depositor (where $M<1$ ), illus. trated in figures $11-13$. Under this arrangement, the depositor receives the full deposit amount, $\mathrm{L}$, in the event of any insolvency or shortall, up to the amount, $M$, of the coverage limit. Thus, the depositor's portfolio contains the deposit amount, $L$, and he has written a pul option on the bank's assets with striking price $(L$ - M). This put option is the result of the maximum coverage limit. The FDIC holds the put option with striking price $(\mathrm{L}-\mathrm{M})$, but has writ ten a second put option on the bank's assets with striking price $L$. As before, this put option (with striking price $\mathrm{L}$ ) is held by the banker, who also owns the assets and owes the amount L to the depositor.

Because of the put option written by the depositor and held by the FDIC, the depositor now shares in the risk of the bank's assets. His deposit is now worth less, and he will discount the promised payoff more steeply. Extending the example given above for the case of 100 percent coverage, the depositor's portfolio, which contained only the riskless deposit, worth $\$ 932.12$ when discounted, is now augmented by the put option written with a striking price of $(\mathrm{L}-\mathrm{M})$. If, for example, the coverage limit is set at $\mathrm{M}=$ $\$ 100$, so that the striking price is $\$ 900$, then with $\sigma=0.3$ percent, $R=8$ percent and $A=$ $\$ 985$ as before, the Black-Scholes value of this put option to the depositor is $-\mathrm{P}=-\$ 47.96$, and the total value of his portfolio is $\mathrm{D}=$
26The original limit was $\$ 2500$ under the Banking Act of
1933; see FDIC (1984), pp. 44, 69 . The impact of the
coverage ceiling is limited by the availability of brokered
deposits and by the tendency of the insurer to arrange
purchase and assumption solutions to bank fallures.
27There are other possibilities. For example, deposit in-
surance in the United Kingdom involves fixed proportional
sharing combined with a coverage celling Isee Llewellyn
(1986), p. 20], and a temporary deposit insurance program in the United States was to have sharing in staggered proportions [see FDIC (1984), p. 44]. Analyses of co-insurance tend to focus on proportional sharing arrangements. See Boyd and Rolnick (1989), and Benston and Kauman (1988), ch. 3 .

${ }^{28}$ Defining a "healthy" asset is a difficult chore. The task is generally accomplished by individual evaluation of assets, rather than the application of a generic rule. 


\section{Figures 11-13}
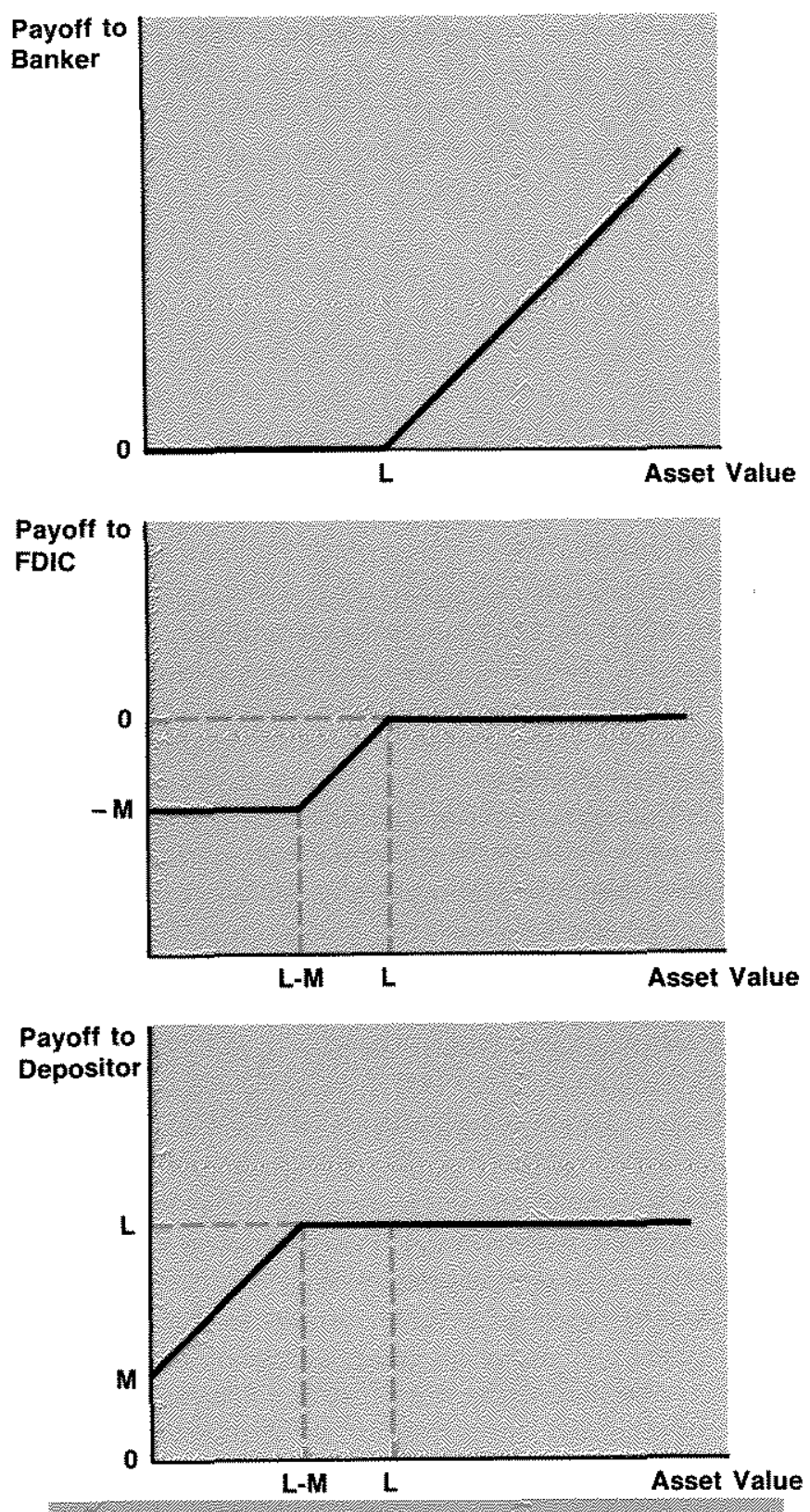

$\$ 932.12-\$ 47.96=\$ 884.16$. In other words, given deposit insurance with a $\$ 100$ coverage limit, $\$ 884.16$ is the amount deposited at the beginning of the year in exchange for a prom. ised year-end payoff of $\$ 1000$.

In general, we can use an option pricing model to solve algebraically for a measure of

29For some examples of market discipline proposals, see Boyd and Rolntck (1989), Gilben (1990), Gorton and Santomero (1988, 1989), or Thomson (1987).

30 Note that uninsured or cominsured depositors might find in more practical to engage in capital rationing, i. e., limiting the risk premium that the depositor would charge under this risk-sharing arrangement. On the one hand, we can think of the deposit as a riskless deposit combined with a put option. On the other hand, we can think of it as a single risky promise of repayment from the banker, to be discounted at some risk-adjusted interest rate, $r$, so that the value of the deposit is:

$\mathrm{D}=\mathrm{L}^{\cdot} \mathrm{e}^{-\mathrm{TT}} \cdot \mathrm{We}$ can equate these two interpretations thus:

$$
\begin{aligned}
D & =L \cdot e^{-R T}-P(L-M, A, T, \sigma, R) \\
& =L \cdot e^{-r T},
\end{aligned}
$$

where $\mathrm{P}(\bullet)$ is the value of the put option before expiration, as defined, for example, by the Black-Scholes model, and $r$ is the risk-adjusted discount rate implied by the presence of the coverage limit. Given the other variables, we can rearrange this to find the risk premium:

(2) $(\mathrm{r}-\mathrm{R})=-\frac{1}{\mathrm{~T}} \ln \left[\mathrm{e}^{-\mathrm{RT}}-\frac{1}{\mathrm{~L}} \mathrm{P}(\bullet)\right]-\mathrm{R}$.

Applying this to the numerical example, the stated risk-adjusted interest yield on the deposit is:

$$
\begin{aligned}
\mathrm{F} & =-\ln \left[\mathrm{e}^{\mathrm{m.08(1)}}-\frac{\$ 47.96}{\$ 1000.00}\right] \\
& =-\ln (0.87515)=13.3 \%_{f}
\end{aligned}
$$

implying a risk premium, $r-R$, of 5.3 percent.

In practical terms, such an estimate of the magnitude of the risk premium implied by a given coverage ceiling might be useful in calibrating the degree of market discipline in a reform of the insurance system. If bank risk-taking is to be curbed by limiting deposit insurance, forcing riskier banks to pay higher risk premia as some have suggested, then the insurance limitations must be such that the risk premium implied by equation 2 is large enough to make bankers alter their behavior. ${ }^{29}$

The magnitude of the risk premium might also serve as a readily observable vital sign, registering the financial health of the bank's assets, and aiding the regulator in scheduling audits. This presumes that depositors have some advantage over regulators in assessing the bank's risk between audits. ${ }^{30}$ Such applications, how-

the amount lent to a bank based on that bank's risk, in addition to pricing that risk. 
ever, are subject to some limitations which are illustrated by the next example.

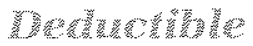

Another form of co-insurance is a deductible. The case of a deductible on insurance coverage introduces a twist to the problem. Now the depositor's portfolio effectively consists of two put options, one written and one held, in addition to the promised repayment of the deposit with interest. This case is of special interest, because it applies to a deposit payout closure as considered above and because it can also be applied to subordinated debt, which is the object of a recent debate on sources of market discipline of bank risk-taking. In both cases, the payoffs to one of the bank's creditors can be modeled as a pair of put options with different striking prices. ${ }^{31}$

In this example, the depositor is promised the return of his deposit amount, with accrued interest, for a total of $\mathrm{L}$ dollars. Because of the deductible provision, however, this promised repayment is not certain; in the event of the bank's insolvency, the depositor will be the first to share in the shortfall. For year-end asset levels below $\mathrm{L}$, the shortfall is deducted from the depositor's payoff until the deductible amount, $\mathrm{L}$, is exhausted. Any shortfall beyond that is absorbed by the FDIC. Thus, the depositor effectively holds the deposit amount $L$ and has written a put option with striking price $L$, that is held by the banker; in addition, he holds a put option with striking price $(\mathrm{L}-\mathrm{U})$, which is written by the FDIC. These payoffs are illustrated in figures $14 \cdot 16$.

The deductible provides a cushion for the FDIC, which, in the preceding examples, had written a put option with striking price $\mathrm{L}$ rather than $(\mathrm{L}, \mathrm{U})$. The year-end payoffs for the banker are the same as before. The real difference applies to the depositor's incentives and the resulting impact on the price he charges the banker for the deposit. Although he always prefers a higher asset value, as before, his attitude toward the riskiness of the bank's assets is now ambiguous, because he is long one put option and short another, with two different striking prices. Volatility in the bank's asset

\section{Figures 14-16}
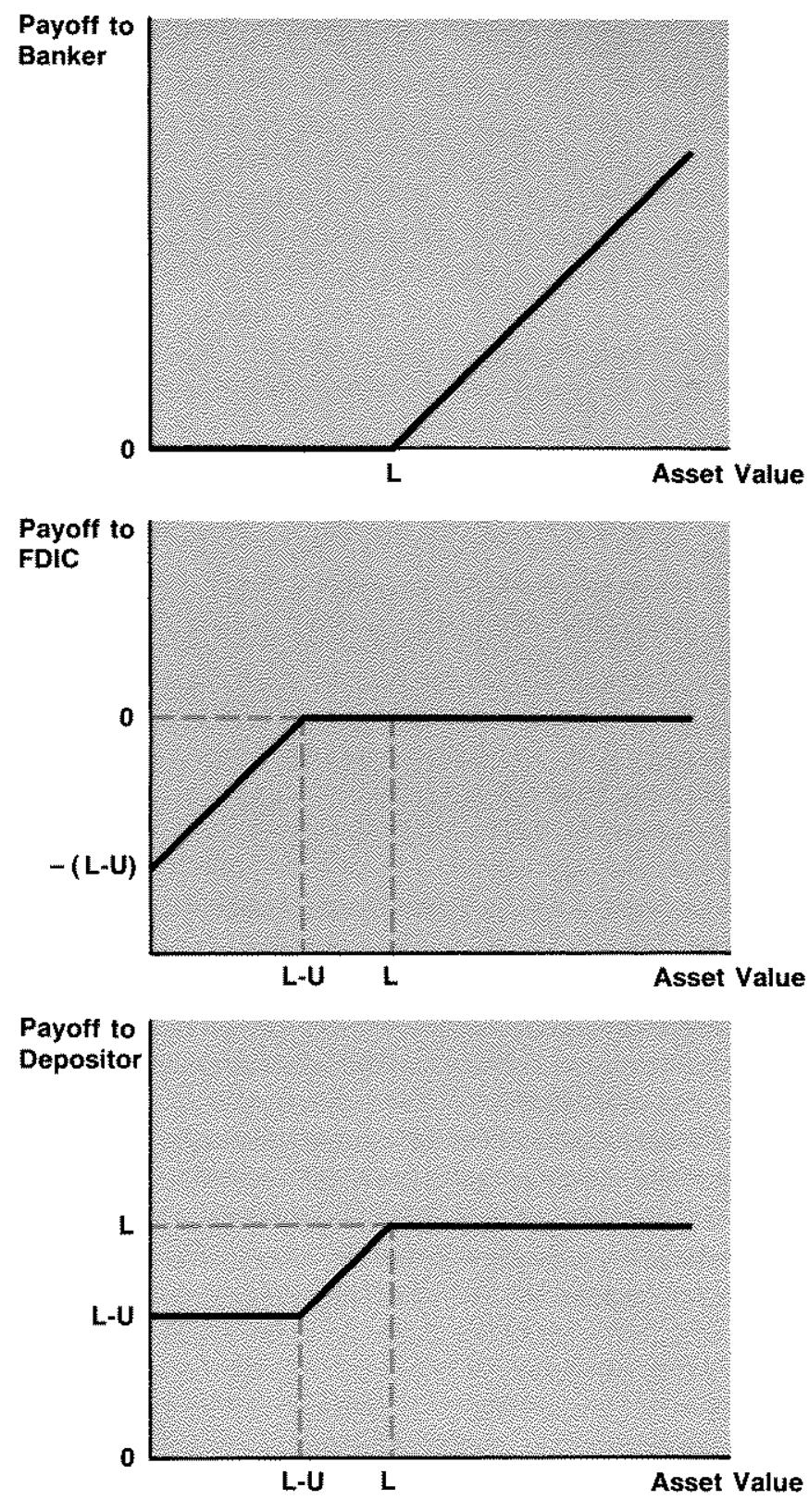

returns increases the value of the long position and decreases the value of the short position.

As Black and Cox (1976) point out, the net impact of these countervailing forces will depend on the current asset value relative to the striking prices. Specifically, there is an inflection

\footnotetext{
3t The relevant creditors in each case are the depositor and the subordinated debt-holder, respectively. For an analysis of option models in the case of subordinated debt, see Black and $C o x(1976)$ and Goton and Santomero (1988, 1989). For an analysis of subordinated debl and bank
}

regulation, see Gilbert (1990). The approach here is at odds with that of Ronn and Verma (1986), who calculate the value for a single put on tolal debt and then scale that value down by the proportion of insured to total liabilities. 
point equal to the discounted geometric mean of the two striking prices. ${ }^{32}$ For an asset value above the inflection point, which includes all cases in which the bank is solvent (i. e., A > $\mathrm{L}^{+} \mathrm{e}^{-\mathrm{RT}}$ ), the effect of the short position outweighs that of the long position, and the depositor will prefer less risk. Conversely, when the current market value of assets falls below the inflection point, the long position outweighs the short, and the depositor would prefer a riskier asset portfolio, given the low asset value. Thus, a decrease in the "risk premium" charged by the depositor no longer necessarily implies that the bank's assets are less risky; for example, such a decrease could instead be the result of an increase in the current asset value and an increase in the volatility of those assets.

Under such circumstances, it is a reasonable taxonomic question whether the interest rate markup over the riskless rate should be called a risk premium at all. The current value of the depositor's claim and the implicit risk premium can be calculated as before:

$$
\begin{aligned}
\mathrm{D} & =\mathrm{L} \cdot \mathrm{e}^{-\mathrm{RT}}-\mathrm{P}(\mathrm{L}, \mathrm{A}, \mathrm{T}, o, \mathrm{R})+\mathrm{P}(\mathrm{L}-\mathrm{U}, \mathrm{A}, \mathrm{T}, o, \mathrm{R}) \\
& =\mathrm{L} \cdot \mathrm{e}^{-\mathrm{rT}} \rightarrow \\
(\mathrm{r} & -\mathrm{R})= \\
& -\frac{1}{\mathrm{~T}} \ln \left\{\mathrm{e}^{-\mathrm{RT}}-\frac{1}{\mathrm{~L}}[\mathrm{P}(\mathrm{L}, \bullet)-\mathrm{P}(\mathrm{L}-\mathrm{U}, \bullet)]-\mathrm{R},\right.
\end{aligned}
$$

but the risk premium so defined is a measure of the expected difference between cash promised, L, and cash ultimately received. It is a poor measure of the volatility of the returns on the bank's assets, because the expected difference between cash promised and cash received depends on several factors and is no longer a simple direct relation of the volatility of assets.

Figure 17 graphs the value of the depositor's claim for a range of asset levels and volatilities. ${ }^{33}$ In interpreting this graph, note the connection between it and figure 16. In particular, as the volatility, $\sigma$, goes to zero in figure 17 , the value of the deposit resembles more and more the staggered year-end payoff function of figure 16. In fact, if the year-end payoff of figure 16 is scaled down by the risk-free present value discount factor, $e^{-\mathrm{RT}}$, it becomes identical to the extreme case of figure 17 where $\sigma=0$. Figure 17 also illustrates graphically the Black and Cox argument that for some (higher) asset levels, depositors will charge a risk premium, while for other (lower) levels, they will offer a risk discount.

It is also clear from the picture, however, that the asset level has a much more significant effect on the value of the claim than does the volatility ${ }^{34}$ All of this suggests that bankers, depositors and policymakers should give considerable care to an appropriate definition of risk in this context, and that similar care should be given to designing a practical measure of that risk. Risk defined as volatility in bank asset returns and measured by the risk premium charged on equity, subordinated debt or uninsured deposits may not be apt for the tasks to which it has been applied.

\section{SW}

The preceding analysis has illustrated some uses of option pricing models in evaluating deposit insurance. There are some limitations, however, on the use of options models in this context. Most of these limitations derive from the assumptions that form the basis for the option pricing equation, and the extent to which these assumptions are valid for the case at hand.

Perhaps the most basic problem is the ques. tion, who truly holds the option. ${ }^{35}$ Until now, it has been presumed, based on the end-of-period payoffs, that deposit insurance represents a put option written by the FDIC and held by the banker. In fact, however, the FDIC decides whether a bank is insolvent, and, more importantly, whether to close a bank that is already insolvent (or one that is not quite insolvent). ${ }^{36}$ In the face of a large-scale bank failure or run,
32The discoun rate used to calculate this inflection point includes a risk premium. Since all other discounting in this context is at the riskless rate, this means that the inflecton point can fall below the present value of the lower discount rate, $(L-b) e^{-R T}$, if the risk premium, $a^{2 / 2}$, is large enough. For the same reason, the intlection point is always smaller than the solvency point, $L \cdot e^{-k \text { "k }}$

3 The riskless rate was set at 8 percent, time to maturity was one year, promised repayment was $\$ 1000$, and the deduchible amount was $\$ 200$. Similar graphs with other maturities and deductible amounts reveal no surprises.
${ }^{34}$ This fact is noted by Pyle (1983), p. 13.

35This issue is addressed by Brumbaugh and Hemel (1984) and Alen and Saunders (1990).

36 Pecall that the definition of insolvency used in this paper ignores the possibility that the bank might be deemed in. solven on the basis of its current ratio - i, e., its inability to meet maturing liabilities with liquid assets. This problem relates to the maturity structure of the bank's portfolto, which will be considered briefly below. 


\section{Figure 17}

\section{Value of Depositor's Claim}

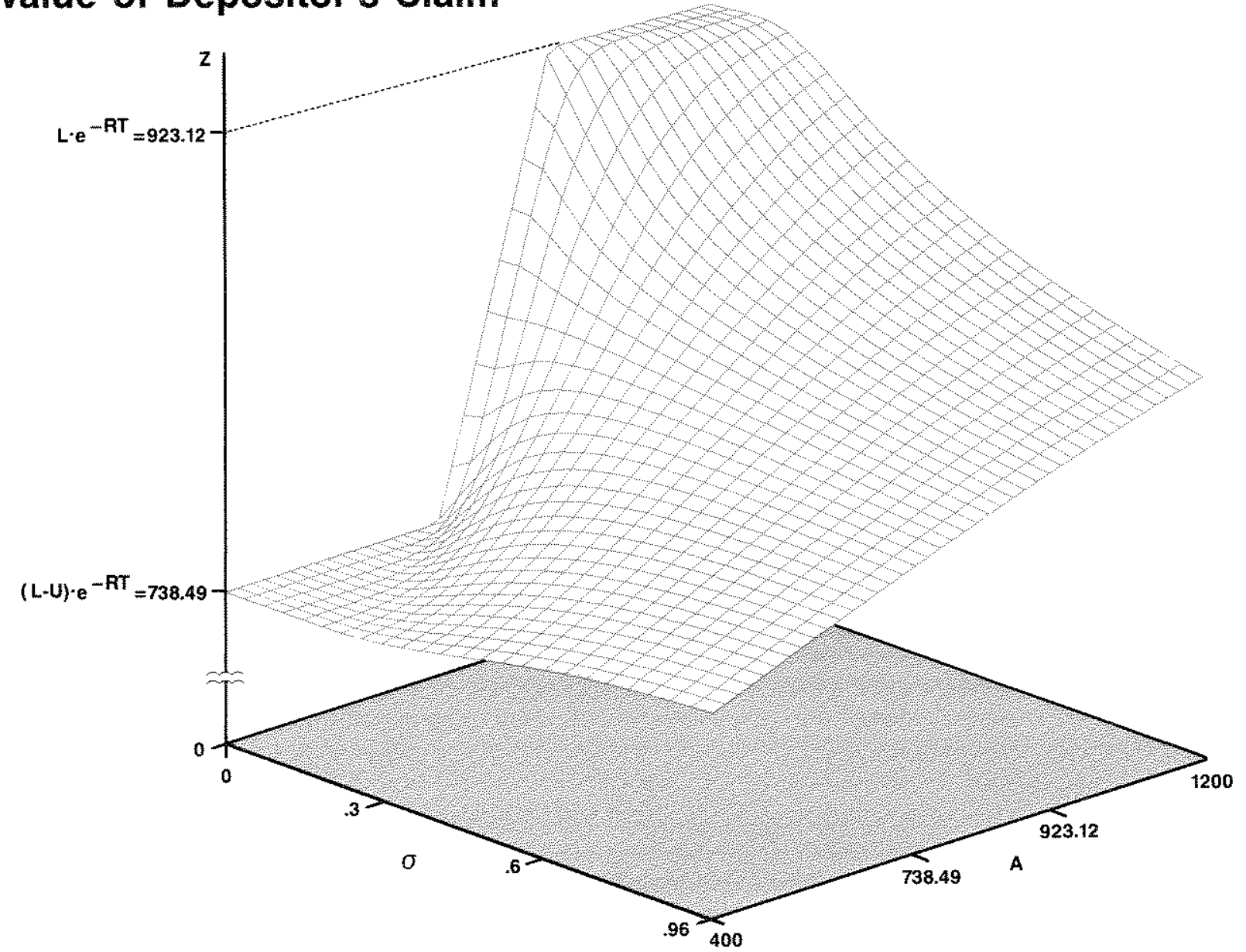

short-term political considerations may overwhelm any prior prescriptions on closure policy. The FSLIC's actions in the thrift crisis indicate that this is not idle speculation; numerous thrifts were left open long after their insolvency had been discovered. Conversely, as Benston and Kaufman (1988) suggest, the FDIC could close solvent banks, if they have come close enough to insolvency. If the insurer were to follow scrupulously a well-defined rule one way or the other, there would be little at issue, since the striking price and yeartend payoffs could then be easily adjusted within the context of the current model. As matters stand, however, bankers and depositors effectively face a random striking price, because the insurer decides if the option will be exercised. As a practical matter, it is difficult to envision how such a well-defined closure rule might be implemented. ${ }^{37}$

A related issue is the measurement of bank asset values. The option pricing model presented above presumes that the current asset price can be readily observed. For stock options, this is an uncontentious assumption, because stock prices can be observed on the floor of the exchange or in the over-the-counter market. For an option on the assets of the bank, however, the relevant price is not readily observable. Indeed, one of the primary functions of bank credit analysis is to assign values to assets for which there is no active market. Similarly,
${ }^{37} \mathrm{~A}$ rule is well-cefined if it leaves no doubt about the cipcumstances which imply closure, with no room for FDIC discretion. Note that defining a closure rule, in general, is not sufficient for our purposes; the closure rule must be defined so that the values of the resultan? claims conform to the values given by the option pricing equation. 
the insurer must invest significant effort, in the form of an audit, to determine the year-end asset value.

The inherent inaccessibility of bank asset values has two implications for option models. First, it is no longer possible for an option holder to construct the appropriately hedged portfolio described in the Black and Scholes derivation, because the hedge ratio depends on the value of the underlying asset. This casts doubt upon the appropriateness of the riskless rate in discounting the expected end-of-period payoffs. ${ }^{38}$ Second, the current asset value is important, because it partly determines the probabilities for the various end-of-period payoffs. Ignorance of the current asset value adds another layer of uncertainty, and this additional uncertainty significantly affects the value of the option. ${ }^{39}$

A closely related issue is the measurement of asset risk. The option pricing models presented here use the variance of the asset's returns as a measure of risk ${ }^{40}$ Producing an accurate assessment of the variance is problematic, even for stock options, because the volatility that matters is the variance of the process over the future life of the option. For bank assets, the measurement problem is compounded, because even past values are generally unavailable. Pyle (1983) and Flannery (1989b) consider some of the implications of this problem in using the option models to price deposit insurance.

Just as asset values and the volatility of returns are not observable directly, there is the more general moot question of which stochastic returns-generating process should be incorporated in the option pricing model. As we've seen above, the difference in the assumed returns process between Black and Scholes's model and Merton's model resulted in a substantially different pricing equation. Although the choice of an appropriate returns process for modeling a bank's assets is beyond the scope of this paper, it is sufficient to note

${ }^{38}$ One might resort to the argument that the riskless rate is appropriate if the asset has no idiosyncratic (that is, firmspecific) risk, as noted in the context of Merton's (1976) pricing model (see the shaded insert), but such an assumption is not particularly credible for bank asset portfolios, prima facie.

${ }^{39}$ See Pyle (1983) for an analysis of asset value uncertainty. Figlewski (1989) and Babbel (1989) consider the impossibility of hedging, along with many other difficulties in the application of stock option pricing models.

40Merton's (1976) approach uses that variance together with the parameters of the jump distributions. that this choice is a salient factor in the option's value, because it determines the probability of each of the possible year-end payoffs.

The empirical evidence to date testifies to the sensitivity of the results to the specification employed. Marcus and Shaked (1984) use the basic black-Scholes model, adjusted for dividends, and find that federal deposit insurance is currently substantially overpriced relative to the "actuarially fair" estimates provided by their option model.41 They note, however, that "McCulloch's $(1981,1983)$ estimates of insurance values derived from the Paretian-stable distribution greatly exceed" their own. ${ }^{4 z}$ Pennacchi (1987b) uses a more complicated model which includes the degree of regulatory control wielded by the insurer. He finds that deposit insurance may be either overpriced or underpriced, depending on the level of regulation assumed. McCulloch's (1985) study assumes non-normal, Paretian-stable asset returns and non-stationary random interest rates. He finds that insurance values are highly sensitive to the level and volatility of interest rates. Ronn and Verma (1986), however, using a variant of Merton's (1977) model, conclude that neither random interest rates nof non-stationary equity returns significantly affect the insurance valuations. In brief, the empirical evidence suggests that a wide range of insurance valuations can be reached by varying the returns process employed in the model.

Finally, it has been assumed in the preceding examples that there is a single deposit that does not mature until the end of the year. In fact, of course, banks maintain many deposit accounts with a wide range of maturities, starting with the instant maturity of demand deposits. This is significant, because it gives many depositors another type of insurance. A depositor who can withdraw his funds from a failing bank sooner than the FDIC can close it has 100 percent insurance, regardless of the balance in the account or the insurance scheme in effect. ${ }^{43}$ The

41For an exposition of the dividend adjustment to the BlackScholes model, see Merton (1973).

42Marcus and Shaked (1984), p. 449. Thejy reference to McCulloch (1983) was a working paper, later published as McCulloch (1985).

${ }_{43}$ It need only be the case that the bank funds the deposit outflow somehow, for example, through a fire sale of its assets. Such a run on Continental llinois by institutional depositors prompled the FDIC to extend 100 percent insurance to uninsured depositors. 
result is that the simple application of an option pricing model does not provide an accurate evaluation of such deposits, because it ignores certain relevant strategies.

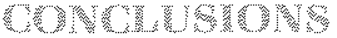

The usefulness of option models in the study of deposit insurance results from two important characteristics. First, these models distill the host of economic factors involved down to a handful of relevant parameters whose interaction is well-defined by the option-pricing equation. Second, they are able to evaluate deposit insurance claims under a wide variety of insurance structures. Although only three such structures were elaborated here, they can be generalized to other applications. Thus, option models provide a unified context for analyzing incentives within an insurance structure, as well as for comparing alternative insurance schemes.

Unfortunately, option pricing models, like most economic models, are an imperfect tool when directly applied to the complexities of the real world. Beyond certain fundamental qualitative results, there are theoretical and empirical reasons to believe that the insurance valuations given by any particular option pricing model will be incorrect, highly sensitive to changes in their specification, or both. As a result, the absolute dollar magnitudes provided by options models of the value of deposit insurance are suspect. The contradictory empirical evidence on fair pricing is indicative of this problem.

In defense of these models, however, there is no reason to believe that option models are any worse in this regard than any alternative economic model. Indeed, there is some reason to believe that, although the absolute magnitude of the valuations provided by option models may be unstable, the rankings they provide for a sample of banks are not. ${ }^{44}$ Similarly, inaccuracies in determining the scale of insurance values do not deny the ability of option models to identify the direction of incentives or the impact of marginal changes in the structure of deposit insurance. Therefore, used judiciously, option pricing models can be an effective analytical tool in the study of deposit insurance.

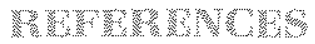

Allen, Linda, and Anthony Saunders. "Forbearance and Deposit Insurance Valuation," Working Paper, Baruch College, City University of New York, January 1990.

Babbet, David F. "Insuring Banks against Systematic Credit Bisk." Journal of Futures Markets (December 1989), pp. 487-505.

Barnea, Amir, Robert A. Haugen, and Lemma W. Senbet. Agency Problems and Financial Contracting (Prentice-Hall, 1985).

Barnett, Robert E., Paul M. Horvitz, and Stanley C. Silverberg. "Deposit insurance: The Present System and Some Alternatives," The Banking Law Journal (April 1977), pp. 304-32.

Benston, George J., and George G. Kauman. "Risk and Solvency Regulation of Depository Institutions: Past Policies and Current Options." Monograph Series in Finance and Economics, Salomon Brothers Center for the Study of Financial Institutions, New York, 1988.

Black, Fischer, and John C. Cox. "Valuing Corporate Securities: Some Effects of Bond Indenture Provisions," Journal of Finance (May, 1976), pp. 351-67.

Black, Fischer, and Myron Scholes. "The Pricing of Options and Corporate Liabilities," Journal of Political Economy (May/June, 1973), pp. 637-54.

Boyd, John H., and Arthur J. Rolnick. "A Case for Reforming Federal Deposit Insurance," Federal Reserve Bank of Minneapolis 1988 Annual Report (1989).

Brumbaugh, Dan, and Eric Hemel. "Federal Deposit insurance as a Call Option: Implications for Depository institution and Insurer Behavior:" Working Paper No. 116, Federal Home Loan Bank Board, Washington, D.C. OCtober 1984.

Cox, John C., and Stephen A. Ross. "The Valuation of Options for Alternative Stochastic Processes," Journal of Financial Economics (January/March 1976), pp. 145-66.

Cox, John C., and Mark Rubinstein. Options Markets (Prentice-Hall, 1985).

Federal Deposit Insurance Corporation. Deposit Insurance in a Changing Enwironment, (FDIC, Washington, D.C., 1983). Foderal Deposit insurance Corporation: The First Fitty Years, (FDIC, Washington, D.C., 1984). 1989) 1988 Annual Report, (FDIC, Washington, D.C.

Figlewski, Stephen. "What Does an Option Pricing Model Tell Us About Option Prices?' Financial Analysts Journal (September/October 1989), pp. 12-15.

Flannery, Mark J. "Capital Regulation and Insured Banks" Choice of Individual Loan Default Risks;" Journal of Monetary Economics (September 1989a), pp. 235-58.

"Pricing Deposit Insurance When the Insurer Measures Bank Risk with Error," Working Paper, School of Business, University of North Carolina, May 1989b.

Furlong, Frederick T., and Michael C. Keeley. "Does Capital Regulation Affect Bank Risk-taking." Working Paper No. 87-08, Federal Reserve Bank of San Francisco, 1987.

Gilbert, R. Alton. "Market Discipline of Bank Risk: Theory and Evidence," this Review (January/February 1990), pp. 3-18.
44The rank-order correlation of risk measures for a sample of banks over time [Marcus and Shaked, (1984), p. 455] and over alternative risk metrics [Ronn and Verna, (1987), p. 511] indicate that the stability of the rankings is significant but imperfect. Further research along these lines would be welcome. 
Gorton, Gary, and Anthony M. Santomero. "The Market's Evaluation of Bank Risk: A Methodological Approach," in: Proceedings of a Conference on Bank Structure and Competition, (Federal Reserve Bank of Chicago, May 1988), pp. 202-18.

"Market Discipline and Bank Subordinated Debt;" Working Paper, Wharton Schoof, University of Pennsylvania, August 1989.

Huertas, Thomas F, and Rachel Strauber. "An Analysis of Alternative Proposals for Deposit Insurance Reform." Appendix $\mathrm{E}$ to Hans $\mathrm{H}$. Angermueller's testimony in: Structure and Regulation of Financial Firms and Holding Companies (Part 3): Hearings before a Subcommittee of the Committee on Government Operations, U.S. House of Representatives, 99 th Cong., 2 Sess., December 17-18, 1986 (GPO, 1987), pp. $390-463$.

LLewellyn, D. T. The Regulation and Supervision of Financial Institutions, Gilbart Lectures on Banking, (Institute of Bankers, London, 1986).

McCulloch, J. Huston. "Interest Rate Risk and Capital Adequacy for Traditional Banks and Financial Intermediaries," in S. J. Maisel, ed., Risk and Capital Adequacy in Commercial Banks, National Bureau of Economic Research, 1981, pp. 223-48.

"Interest-risk Sensitive Deposit Insurance Premia: Stable ACH estimates," Journal of Banking and Finance (March 1985), pp. 137-56.

Malliaris, A. G. 'tto's Calculus in Financial Decision Making," SIAM Review (October 1983), pp. 481-96.

Marcus, Alan J. "Deregulation and Bank Financial Policy", Journal of Banking and Finance (December 1984), pp. 557-65.

Marcus, Alan J., and Israel Shaked. "The Valuation of FDIC Deposit Insurance Using Option"pricing Estimates," Journal of Money, Credit and Banking (November 1984), pp. 446-60.

Merton, Robert C. "Theory of Rational Option Pricing," Bell Journal of Economics and Management Science (Spring, 1973), pp. 14ћ-83.

"Option Pricing When Underlying Stock Returns Are Discontinuous," Journal of Financial Economics (Jantary/March 1976), pp. 125-44.

. "An Analytic Derivation of the Cost of Deposit in" surance and Loan Guarantees: An Application of Modern Option Pricing Theory," Joumal of Banking and Finance (June 1977), pp. 3-11.

"On the Cost of Deposit insurance When There Are Surveillance Costs" Journal of Business (July 1978), pp. $439-52$.
Osterberg, William P., and James B. Thomson. "Capital Requirements and Optimal Bank Portiolios: A Reexamination;" Working Paper No. 8806, Federal Reserve Bank of Cleveland, 1988.

Pennacchi, George G. "Alternative Forms of Deposit Insurance," Journal of Banking and Finance (June 1987a), pp. 291-312.

"A Reexamination of the Over- (or Under-) Pricing of Deposit Insurance," Journal of Money, Credit and Banking (August 1987b), pp. 340-60.

Pyle, David H. "Pricing Deposit Insurance: The Effects of Mismeasurement," Working Paper No. 83-05, Federal Reserve Bank of San Francisco, October 1983.

"Deregulation and Deposit Insurance Reform,"

Economic Review, Federal Reserve Bank of San Francisco (Spring 1984), pp. 515.

"Capital Regulation and Deposit Insurance," Journal of Banking and Finance (June 1986), pp. 189-201.

Ronn, Ehud I., and Avinash K. Verma. "Pricing RiskAdjusted Deposit Insurance: An Option-Based Model," Journal of Finance (September 1986), pp. 871-95.

"A Multi-Attribute Comparative Evaluation of Relative Risk for a Sample of Banks," Joumal of Banking and Finance (September 1987), pp. 499-523.

Rubinstein, Mark. "Nonparametric Tests of Alternative Option Pricing Models Using All Reported Trades and Quotes on the 30 Most Active CBOE Option Classes from August 23, 1976 Through August 31, 1978," Journal of Finance (June 1985), pp. 455-80.

Sinkey, Joseph F., Jr., and James A. Miles. "The Use of Warrants in the Bail Out of First Pennsylvania Bank: An Application of Option Pricing," Financial Management (Autumn 1982), pp. 27-32.

Stoll, Hans R. "The Relationship Between Put and Call Option Prices," Journal of Finance (December 1969), pp. 802-24.

Symons, Edward L., Jr, and James J. White, Banking Law (West Publishing, 1984).

Thomson, James B. "The Use of Market Information in Pricing Deposit Insurance," Journal of Money, Credit and Banking (November 1987), pp. 528-37.

U.S. Treasury Department, The Working Group of the Cabinet Council on Economic Affairs. "Recommendations for Change in the Federal Deposit Insurance System" (GPO, 1985).

White, Lawrence J. "The Reform of Federal Deposit insurance," Joumal of Economic Perspectives (Fall 1989), pp. $11-29$. 